\title{
For They Need to Believe Themselves White: An intertextual analysis of Orson Welles's Othello
}

\author{
Nike Jung* \\ Department of Film and Television Studies, University of Warwick \\ *Correspondence: nikejung@gmail.com
}

\begin{abstract}
This article proposes to reassess Orson Welles's Othello (1951) in light of his earliest and little examined short, The Hearts of Age (1934). Refining textual analysis with the tools of whiteness studies and a focus on how American media history is reflected in the film, the article demonstrates that Welles's Othello makes a strong (and often misunderstood or ignored) critical intervention of progressive racial politics, a politics which is, moreover, already located in Shakespeare's original source text.
\end{abstract}

Keywords: Orson Welles, Othello, blackface, minstrelsy

Peer review: This article has been subject to a double blind peer review process

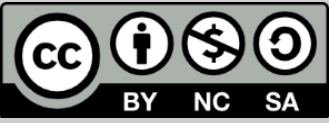

(C) Copyright: The Authors. This article is issued under the terms of the Creative Commons Attribution NonCommercial Share Alike License, which permits use and redistribution of the work provided that the original author and source are credited, the work is not used for commercial purposes and that any derivative works are made available under the same license terms.

\section{The Hearts of Age}

Precious few words have been written about Orson Welles's early experimental film, The Hearts of Age (1934, co-directed with William Vance), the first film of America's then 19-year-old wunderkind. Typically, the eight-minute black-and-white film is framed in terms based on Welles's own claim that the work was essentially a joke. In interviews with filmmaker Peter Bogdanovich, Welles suggested to read Hearts as persiflage on modern and surreal cinema such as Un chien andalou (Luis Buñuel, 1929) or as a parody of The Blood of a Poet (Jean Cocteau, 1930). Critical reflections mention in passing that there appears blackface in the film, only then to move swiftly on to its formal features and the attempt to integrate the work into Welles's oeuvre and in film history more broadly. Consider this assessment, by Brian L. Frye, as recently as 2006:

As a parody of Cocteau, [the film is] an abject failure [...] But its ghoulish make-up, mechanical acting, off-kilter compositions and frantic montage quite successfully parody German Expressionism [... and] the structure of the montage sequences recalls Eisenstein's The Battleship Potemkin (1925), repeating actions and fracturing motions. (Frye, 2006: para.7) 
In terms of narrative content, the film is read as a universal or personal 'parable of mortality' (Frye, 2006: para. 9):

The little film tells in a strange, surreal way of Death (played by Welles in grotesque old-age makeup as a kind of grinning joker) and how he comes to beckon the old lady ... to her grave. (Bogdanovich in Posner, 2001, p. 141)

However, Welles gave his historical parable a specifically US American twang. Where Welles scholar Joseph McBride suggests that the film presents 'a mélange of styles, the conglomeration of postures both congenial and unassimilated, a vigorous, unguarded, personal approach to even the most second-hand of ideas and motifs' (qtd in Frye, 2006: para. 6; my emphasis). Hearts in fact presents a culturally specific vision of death. It is remarkable that these evaluations ignore how the presence of blackface in the film provides a targeted reference to US-American media history, and that its appearance in Hearts, alongside the motif of lynching and symbols of a deadly whiteness, gives a racial subtext to the theme of death.

What happens in this little black-and-white film is the following:

a man in black-face [pulls] the bell rope, with the old lady on the roof above him [...] We see a hand spinning a globe in close-up and then a striking shot [...] a gray tombstone, dizzily tilted, with a shadow hand creeping up it and beckoning with a long finger [... this white] character is [...] making a choking gesture with his cane for the man in black-face. (McBride, 1976: 100-01; my emphasis)

What is omitted in analyses such as this one is the fact that this creeping shadow turned white, because the shot is in negative, and that this whiteness is connoted with the symbols of lynching, from the choking gesture onwards: 'From the smiling Death, Welles cuts to a skull, to a yanking rope, to a pair of feet hanging in mid-air, and to the head of the black-faced bellringer.' (Gottesman, 1976: 102) After the white man, interpreted as Death, makes a choking gesture to the person in blackface, there is a sequence which intersperses the shouting faces of this figure and the (white) old lady with the person in blackface, ending in an image of a skull and the blackfaced character dangling from the rope. Then there is a shot of a skull in negative, so that the skull is black.

Moreover, hints at a sexualised relation between the blackface figure and the old lady presage the theme of miscegenation - a word to describe the 'mixing of races': as the figure in blackface is yanking the rope, the old lady is 'riding' the bell in a lascivious movement, as a string of men, looped in the editing, appear to beckon or proposition her. 
In the following, I suggest that Hearts should be reconsidered as a very specifically placed allegory which should be contextualised and read within US race relations. This intertextual reading of the use of racial themes in Hearts will illuminate the understanding of Welles's use of blackface and whiteness in his later, controversially interpreted Othello (Welles, 1951). Offering important thematic precursors, Hearts will take its place, alongside Welles's seminal Citizen Kane (1941) in my intertextual analysis, which seeks to demonstrate how Welles highlighted critical themes already present in Shakespeare's source text, translating them into cinematic means that critically intervene in contemporary politics.

Such an analysis is supported by biographical information on the director. Robert Stam characterised Welles as a 'premature anti-racist' (1995: 236), enumerating examples of Welles's unusually intensive engagement in these matters; and Bill Simon documents Welles's 'imprint' during a politically progressive time, as well as his 'theatrical heteroglossia' (1989: 9), demonstrating a vast knowledge of both European and American art, of high and popular culture, which enabled him to move effortlessly between styles and make use of techniques such as blackface purposefully. Such factors predestined Welles to create a version of Othello which highlights not only critical notions already present in the original, but also establishes a link to current politics via US media history.

\section{Colour Politics: Blackface}

The blackface used in Hearts and Othello points to its origin in so-called minstrel shows. Alongside vaudeville and amusement parks such as Coney Island, minstrelsy was one of the most popular forms of entertainment in America of the nineteenth century, demonstrating how the development of American media history is closely interrelated with its racial past.' In minstrel shows, the actors' faces were painted with charcoal, their mouths exaggerated in clownish red, and their performances melodramatically exalted (one origin of the later silent film acting style). Possibly the first genuinely American media format, the shows featured stereotypes of African-Americans, such as the eye-rolling 'plantage blackie' and the lazy urban dandy. Where the 'happy-go-lucky darky' loves watermelons, fried chicken, and dancing, the dandified 'coon' attempts, in vain, to pass as white. Both types demonstrate 'aberrant' sexual behaviour, an uncivilised drive that needs to be controlled. In minstrelsy, fear of a 'nigger rebellion' and loss of racial(/sexual) privilege is evoked and symbolically neutralised, affirming the superiority and identity of white supremacy. Minstrel shows are considered as one of the cultural mechanisms of the 'melting pot' construct, which allowed European immigrants to 'become' Americans: to shift the boundary away from the European distinctions between ethnic or 
religious groups such as Irish and English, and towards the construct of different human races, ${ }^{i}$ a system wherein white people take the highest position.

From a biological perspective, this system is based on a false premise, namely the notion of separate human races:

Modern-day scientists tell us that whites and blacks have more genes in common than the ones that distinguish them - the variability between the average white and the average black, in genetic makeup and physical appearance, is less than the variability within each group. (Delgado and Stefancic, 1997: 13)

Only a small number of genes contribute to skin colour, which is, moreover, inherited independently of other characteristics typically used to differentiate between races, such as hair texture (Delgado and Stefancic, 1997: 13). Our obsession with and markers for race are psychological, not scientific.

The negative connotations of blackness are deeply rooted in the English language. Already in the early sixteenth century, variations of 'blackness' express a link between blackness and hell, evil, sin, and dirt; words such as 'blackmail', 'look black', or 'black magic' contrast with harmless 'white lies' or the innocence of a 'white vest'. iii

Shakespeare's play is soaked through with plays on these expressions. The terms black/white, and fair/dark are frequently set into contrast in a way that Newman characterises as rhetorical miscegenation' (1994: 126). Welles's film emphasises this contrast through cinematic means: from filming in black and white, the choice of costumes, fades to white, his much-commented play on shadows and patterns such as latticed fences, to high noon lighting, which often divides even faces in two.

Some critics have interpreted this emphasis on the black/white discourse in negative terms. Welsh claims that the film reduces the racial theme of the original to aesthetic and technical bravour, 'anatomizing of the politics of representation' and 'deracializing race, reducing the murderous conflict of black and white to a geometric-cinematographic grid' (2002: 190). Where Jorgens claims that 'Welles' use of light and shadow [...] leads us away from clean-cut oppositions and toward ambiguity' (1977: 68), Welsh finds that 'the quick cutting and splicing of the film, like the way it is lighted, serves to keep black and white separate [...] elements of distinction, separation, and refusal to blur' (2002: 189). When historicised and read in the context of Welles's oeuvre, however, it becomes clear that the emphasis on the black/white discourse not only translates but also critically intervenes in racist colour politics. 
Already Shakespeare's play highlights constructed expectations regarding race, which are partly redeemed, partly undermined and partly corrupted: 'instead of participating in the othering promoted within these texts and within his earlier play, [Shakespeare] invokes the stereotype of the Moor as a means of subverting it.' (Bartels, 1990: 447) Certainly, the strategy to call upon the stereotype 'as a means of subverting it' opens the text to divergent interpretations. In the play we are first presented with a defamatory description of Othello, which corresponds to the usual stereotypes about the threatening sexuality of black men. Only when Othello speaks himself, in a scene in which he is being honoured by the Venetian Senate, do audience members realise that he does not at all conform to the stereotype. Revealing information in this chronological order confronts viewers with their own racially determined expectations.

The film, by contrast, instead of building up expectations and tension in this way, immediately introduces the audience to Othello, giving his name and social rank. Where in Shakespeare's play, lago - an anonymous speaker at this point - evokes a distorted image of 'the Moor' in the film, the known voice of the director introduces the figures of Othello and Desdemona in voice-over, summarising what unites and what separates them. ${ }^{\text {iv }}$

However, we only see Othello, alive and in blackface after having heard lago's diatribe," after having seen his scheming to have him accused of bewitching Desdemona. In different ways, both the play and the film tease our mental image, evoked by the preceding descriptions. Welles shapes his Othello into an enigma not dissimilar to the protagonist of Citizen Kane, where the central riddle of the film - Who is Charles Foster Kane? remains unsolved. Both Citizen Kane and Othello use our sensual perception to bring to the foreground our core beliefs and to point to a meta-story about the nature of truth itself.

As in Kane, the film uses a circular narrative style. Framing the main narrative, Othello begins and ends with lago's cage dangling above the funeral procession, given to/for those he has brought down. During the film, lago is sometimes seen walking below this cage, as if to remind the audience, in best tradition of tragedy, of what is to come. Seeing this caged lago at the beginning makes clear that this film is not about suspense, a whodunit, but a particular rendering of the material, an exploration of how to arrive at the beginning.

\section{Othello, the Moor of Venice}

While the film's perspective is not clearly attributed to any one character throughout, the eponymous title character is clearly a figure of sympathy, 
even identification. Othello's lines remain almost intact while other figures' parts are slashed, pushing the film to just about 90 minutes' length. Modernist gestures such as expressive angles, ${ }^{\text {vi }}$ and the subjective camera allow the viewer to form an emotional alliance with Othello's heightened affects. In the vertigo scene, for instance, Othello's confusion is rendered palpable to the audience through the disorienting movements of a camera in whiplash. The soundscape draws us more deeply into the intimacy of this horrible scene between Othello and Desdemona: as we watch Othello smothering Desdemona, 'There is a sighing on the soundtrack, a gong, a beeper, the thud of heartbeats, and then a chilling silence' (Rothwell, 1999: 79).

The alignment with Othello is encouraged, moreover, by the body and voice of director Orson Welles himself, who impersonates the title character. Welles's star persona had been well established at the time of shooting. The charismatic multi-talent had become popular with his radio and theatre plays during the New Deal of the 1930s and early 1940s. vii Therefore, not only Welles's face and his corpulent body, but also his baritone voice and his impressive ability to modulate its register were easily recognisable and familiar. ${ }^{\text {vii }}$ Othello begins with Welles reading a voiceover, setting the stage, and hinting towards the proximity of the narrative agency, or the film's 'voice', to its title character.

The fact that Welles portrays Othello in minstrelsy make-up emphasises rather than hides the mask. Welles's own skin - invisible but known - is a constant reminder of the surface, the performance, a disruption of any illusion, turning Frantz Fanon's concept of 'black skin/white mask' on its head. In Fanon, this dichotomy expresses the divided self-perception of black people who, having interiorised the notion of their native culture as inferior, try to imitate the culture of the coloniser (Fanon, 1967: passim). In Welles's use, the blackface expresses sympathy and solidarity, rather than cultural appropriation, an analysis supported by the contextualisation of the film in the director's oeuvre. Besides my points on Hearts, compare Eric Lott's reading of Touch of Evil (Welles, 1958) as a counter-hegemonic representation of whiteness:

In Welles's counternarrative, the law comes in the form of Mexican Mike Vargas, whose nemesis is the bloated, criminal, white police detective Hank Quinlan (Welles). That Vargas is played by none other than a brown-faced Charlton Heston [...] wittily communicates (to use Homi Bhabha's terms) his notwhite and yet not-quite-Mexican status with which Welles teases our perception of justice's racial tropes. Vargas's brownness curiously (and I think, purposely) oscillates in and out of focus as we forget and remember that this is after all 
Charlton Heston, undermining the simple demarcation of whiteness. (1997: 99)

In both cases, Welles uses brown- and blackfacing of well-known whiteskinned men 'to tease our perception of racial tropes'. As Othello's face becomes increasingly darker, the film visualises lago's success at injecting a racist and misogynist discourse in Othello's self-image, signalling again our proximity to Othello's perspective. lago convinces Othello not only that Desdemona is unfaithful but that she must in fact betray him because he is black, Desdemona's love, as far as it existed, was undeserved and must be lost. Again, the film runs alongside Othello's emotional state, as the film's body, too, darkens: 'once lago's plot begins to take hold, darkness spreads into almost every frame.' (Rosenthal, 2000: 9) The film visualises Othello's fractured identity further through distorted and twisted images, culminating in a broken mirror.

Only in Venice, during the happiest moments between Desdemona and Othello, are there shades of grey in the film - a reflection of a time when the racist pulls and perceptions were not yet separating the lovers. In contrast to the city topography of Venice, in Cyprus, sea and skies are wide and towering over tiny humans (Jorgens, 1977: 24), and the lovers are seen more and more at a physical distance. Desdemona's hair is another expression of the lovers' situation. Where her Venice hairstyle is set in a complicated coiffure, her hair is initially worn open on Cyprus, and caught in a fishnet at the end. Concurrent with the increasing spatial distance between the lovers, claustrophobia spreads through the film: shadows creep over threatening, massive walls, giant empty rooms seem to weigh down on their inhabitants, images of domes and cellars dominate, a confusing topography of inner rooms is threaded through with visual imagery of meandering nets, lattices, close-meshed networks, representing lago's traps. These motifs - the trap, the net, and the cage thread throughout the film. In one of last images, the camera ogles Othello from above, as 'Respectable citizens peer down on [Othello] through an open dome as if he were an ape in a cage' (Rothwell, 1999: 78). White emphasises the colonial aspect of this setting, to which the film points with frequent images of flags, canons, trumpets and ships:

all the characters are in fact placed in kind of enforced solitude as claustrophobic group in an alien land. Basically, they are living in a military garrison holding uneasy power over a people whose language they almost certainly do not speak. [...] It is fundamentally a society of men where the soldiers dominate the prevailing attitudes. (1986: 94)

The narrative agency, not entirely congruent with any one character's point of view, envelops all figures with a vertiginous, tense atmosphere, 
where 'images of depths [...] enforce a sense of a fallen world; [Welles] contrasts such images by placing his characters in dangerously high places when they are particularly vulnerable' (Buchmann, 1991: 140). Othello's loss of a sane, whole self also expresses a central topos of the AfricanAmerican experience where the notion of 'double consciousness' describes the brutally split identity of a subject that is forced, to guarantee survival, to look at him- or herself always also from the outside, through the eyes of its colonisers or oppressors. Similar concepts appear in postcolonial theory, for instance Frantz Fanon's 'split subject' or Homi Bhabha concept of strategic mimicry as a 'double vision.' (1994: 88)

With regards to the play, critics suggest that Othello's skin colour serves as a 'political colour rather than precise shade of non-whiteness', as 'marker of religious difference' (Burton, 1998: 50). Shakespeare's Othello is a Christian, in contrast to Giraldi Cinthio's Hecatommithi (1565), which seems to have served as inspiration. This fact is important, for during Elizabethan times religious boundaries were more important than racial hierarchies, which had only started to develop: 'For the man in the street the decisive line was not between whites and colored people but between Christians and pagans.' (Sjögren, 2002: 58; Sjögren also emphasises the religiously motivated hatred against the Jews) Othello attempts to escape his religious stigma through conversion to Christianity. The film signals institutionalised religion as complicit with a repressive society, for instance by showing lago's devotional behaviour or by having church bells ring at pivotal moments.

\section{Colour Politics: Whiteness}

Continuing the argument that the film must be read through the racial prism of US. history, the casting of the Irish actor Micheál MacLiammóir to portray lago offers an interesting intertext. In the racial hierarchies of the nineteenth century, the 'Irish race' or the 'black Irish' were ranked along with or just barely above black people.

The discrimination against the Irish on the basis of 'race science' highlights how much the notion of race is a historically, culturally and socially fluctuating category. It is exactly that kind of invisible normativity which Whiteness Studies strive to make visible. To paraphrase comedian Chris Rock, what is commonly described as 'black progress' is in fact the progress of white people: ${ }^{\text {ix }}$ to white people, whiteness appears as normal and unmarked in everyday speech and perception. Turning towards this blind spot, the field of Whiteness Studies interrogate what whiteness may signify, especially, but not only, for non-whites. 
Whiteness is centrally connected to death, or to those who bring death: zombies, vampires, or corpses. The complementary stereotype paints blacks as childlike, instinctive, and 'natural' - more in tune with their bodies and their bodies' facilities, from singing or physical activity to sex. Referring to this contrast, film scholar Richard Dyer hits the nail on the head, 'If blacks have more life, then whites have more death' (1997: 59). Another inaugurating scholar of the field, Nobel prize winning scholar and author Toni Morrison, writes about deathly whiteness in key texts of American literature, such as the quest for the white whale in Herman Melville's Moby Dick. Morrison argues that

images of impenetrable whiteness appear almost always in conjunction with representations of black or Africanist people who are dead, impotent, or under complete control [...] these images of blinding whiteness seem to function as both antidote for and meditation on the shadow that is companion to this whiteness.

(1990: 33)

What form does this whiteness take in Othello, then? In Othello, three important figures represent forms of whiteness: Othello, as a hybrid figure, a white person in blackface, who kills the unfortunate Desdemona, embodiment of blind innocence, ${ }^{x}$ and the blinding, manipulative, doublefaced lago who, in the words of Ta-Nehisi Coates, pace James Baldwin, needs to 'believe himself to be white': 'And [they] have brought humanity to the edge of oblivion: because they think they are white.' (2015: epigram) In the film, lago's very first words are 'I have told thee often, and I retell thee again and again: I hate the Moor.' Cutting the preceding extended dialogue between Roderigo and lago in Shakespeare's original highlights how lago's identity is centrally tied to his racist hatred of Othello. Where the play alludes to a number of possible reasons for lago's hatred - such as jealousy or vindictiveness for having been passed over a promotion - no motive at all is offered in the film. lago's hostility seems without cause or end, or as an end in itself, a racism that offers emotional stability.

Our first image of lago is his reflection in the water, as he says, paradigmatically, 'I am not what I am': he is and is not his surface image. In contrast to this controlled and strategic use of appearances, Desdemona's whiteness corresponds to that of an empty, untouched or virginal canvas and when Othello believes her to be 'soiled' by unfaithful sexual relations, she loses the protective sheen of this whiteness. Already in the play, Desdemona seems to present a foil for the phantasies of others: 'In a male world of "reputation," "honour," [and] competitiveness [... Desdemona's] human capacities for trust, sympathy and self-effacement are disregarded and demeaned, while false images of lust and promiscuousness are foisted upon her.' (White, 1986: 89) 
In Welles's film, Desdemona seems defenceless against the inscriptions, phantasies and accusations of the men around her. Played by the alabaster-white Suzanne Cloitier, Welles's Desdemona appears emphatically childlike and naive. Gone are those parts of the play where Desdemona plays an active part in the relationship with Othello, or where she describes a pragmatic vision of a long, sexually fulfilled life that contrasts with Othello's romantic reveries. The scene in which Desdemona attempts to reassure Othello about his perceived rival Cassio provides a good example for how the film translates the perceptions foisted upon her. As Desdemona claims to use her influence on Cassio on behalf of Othello, the wind presses her white dress tightly onto her body, highlighting a sexual silhouette whose curvatures seem to belie her words.

\section{Miscegenation}

Several scholars of the play highlight the historical contingency of misogynistic patriarchy and racial supremacy; 'woman' and 'coloured' inhabit the same othered, non-normative space. Feminine sexuality and blackness represent the feared other: 'femininity is not opposed to blackness and monstrosity, as white is to black, but identified with the monstrous, an identification that makes miscegenation doubly fearful.'

(Newman, 1994: 126) The false accusations against Othello and Desdemona run parallel: 'The play is structured around a significant link between Othello's attempts to prove his wife a whore and lago's efforts to prove the rational general an irrational Moor.' (Bartels, 1990: 447) However, while Othello participates in the stereotypical inscription of his wife, she treats him as she perceives him to be, not as her sociocultural milieu and paternal upbringing would tell her. ${ }^{x i}$ Although Othello initially wishes to be 'free and bounteous' to his wife, he increasingly limits her voice. Desdemona 'is trapped in a world where the sinister advice of lago [...] "be a man!" [...] draws our attention to the dominant creed, a world where the woman must satisfy the man in all activities or be denounced like [lago's wife] as a shrew (White, 1986: 84). Initially Othello's ally, his assurance and proof of his integration, Desdemona is made into an 'Other,' a hybrid that cannot stand - as a woman, she is beneath him, as a white person, she carries higher standing. When Othello decides to kill her, he acts in the name of patriarchy - 'else she betray more men' - but he also believes to transcend his race by putting her into her place. With the barbarous act of murder, he proves his 'conversion' to the hierarchies of a misogynist white supremacy, killing both the possibility of mixed-race offspring and a sexually desiring female agency.

The question of race has always accompanied Othello, prompting Ben Okri to assert that 'even if Othello was originally not a play about race, its 
history has made it one' (qtd in Loomba, 1998: 150). Initially considered vulgar, Shakespeare entered American mainstream via vaudeville and minstrelsy. Early critics rejected Othello on racial grounds, resenting a black hero. Sexual unity between a white, virginal, socially high-ranking woman with a black man, regardless of religion or social status, was considered an unsupportable violation of ideological taboo. Rymer finds a black general implausible (qtd in Ogude, 1997: 152); Coleridge denies Othello has potential to be a hero (qtd in Bartels, 1990: 448); even in 1958, Ridley proposed that Othello might have been black but certainly not a 'nigger type' (qtd in Newman, 1994: 126) and as late as 2002, Sjögren claimed that 'where racial awareness is particularly strong, as for example in the American South, it is hardly possible to perform Othello at all' (2002: 59).

In the popular imagination, miscegenation was presented as a danger presented by the 'black brute', a hypersexualised stereotype of AfricanAmerican men, as lecherously preying on helpless, white women. Against this threat, white women's bodies needed to be protected, as did their possession by white men need preclusion. De facto, it was the rape of black slave women by white slave-owners which created a mixed-race population. The infamous 'one-drop rule' declared any person with 'one drop of "black blood"' as black but this 'rule' and its evocation of the pollution of blood has been applied only in one direction. The 'mixed' children of slave owners and female slaves were in turn enslaved, effectively increasing their father's wealth. While this offspring was at times described as a 'favour to the race', the union of white women and black men was painted as a threat to the purity of white communities. ${ }^{\text {xii }}$ Twice in Othello, a little black or mixed-race boy stands, narratively unexplained, next to Desdemona, as if to remind the viewer of potential future offspring.

In the US, the threat of miscegenation hindered real political and social progress: 'Every form of political and economic equality for blacks was depicted as a threat to white racial purity, responded to with fears of interracial sexuality, and argued against on this basis.' (Delgado and Stefancic, 1997: 141) The 'horror of invasion of black/colored men into white man's territory' (Loomba, 1994: 175) is played out over and alongside the fear of independent female agency and sexuality. Therefore, the 'black rapist myth' effectively stilled a doubled threat, perpetuating 'black animalism while obliterating female agency, and thus simultaneously eras[ing] the two most problematic areas for patriarchal racism - the humanity of the alien race and the active sexuality of women' (Loomba, 1994: 175). The stereotype of the black brute, who lusts after virginal white girls can be delineated through the ages, from the seminal Birth of a Nation to the 1980 s discourse on black youth as 'superpredators' 
(q.v. Drum, 2016: passim), and it has always been linked to the killing of black bodies, from institutionalised lynching, spectacle and mass entertainment in the US during the nineteenth century (Hale, 1998: 15354), to contemporary police violence and mass incarceration. Against this background one may understand that critics have accused Welles of playing into the stereotype of the black predator: 'Othello's frame [is a] virtual caricature of the faceless villain in black [... Desdemona's] white face recalls nothing so much as a corpse [... she] continues to beam forth marmoreal whiteness, abruptly crossed by Othello's face which rises like a hungry predator.' (Welsh, 2002: 190) But by taking up existing racial tropes and sexual images in order to expose our distorted perception, Welles follows Shakespeare's lead to evoke and disrupt racist images. For lago's trap can only work "because [lago] voices the "common sense", the repetition of the always-already known, the cultural given' (Stallybrass, 1986: 139). Bartels suggests that Shakespeare invokes the stereotype of the Moor as a means of 'exposing its terms as strategic constructions of the self and not empirical depictions of the Other' (1990: 447).

Both texts work on our perceptions in order to expose precisely these assumptions as constructs. Surfaces are deceiving: the ostensibly honest lago turns out to be evil, while Desdemona, who seemed to act suspiciously, turns out to be innocent. The film translates these deceptive appearances not only in objects, mirrors or distorted angles, but literally through 'doubled' faces. Reading Othello intertextually, in reference both to the source text, to Welles's oeuvre and to his actions as a 'premature anti-racist', demonstrates how the film offers not only a felicitous adaptation of daring potential present in Shakespeare's source text, ${ }^{\text {xiii }}$ but also a precocious critical intervention set in the context of contemporary racial politics via its references to US media history. In Welles's film, blackface demonstrates that Othello's factual skin colour becomes irrelevant, as soon as he is viewed, or perceives himself, as black, monstrous or abject. And yet the film shows that it is not blackness that is evil but the deathly schemings of a white figure accompanying the death of a black man - not unlike the white figure in Hearts which beckons to kill a black man by lynching. 
'The first sound film, The Jazz Singer (Alan Crosland, 1927), features its Jewish protagonist in blackface, arguably a means to become American. Initially white actors dominated (white minstrelsy), after the American Civil War (1861-65), black actors increasingly entered the shows; both wore the hyperbolic makeup.

ii I will use the term 'race' in this text, in full awareness of the construct it describes.

iii Ania Loomba finds 'black = evil, stained with dirt, in a pre-sixteenth-century dictionary' (1994: 167); cf. Butler-Evans (1997: 145) and Sjögren (2002: 47).

iv 'There was once, in Venice, a Moor: Othello / who for his merits in the affairs of war was held in great esteem. It happened that he fell in love with a young and noble lady called Desdemona / who drawn by his virtue, became equally enamoured of him.'

${ }^{v}$ In the first images of the film, we do see the corpse of Othello, not yet contextualised, looked at from above and within dark images, where the blackface is not perceptible.

${ }^{v i}$ Several critics mention Eisenstein as aesthetic precursor, cf. Garis (2004: 150) and Rothwell (1999: 77).

vii The most (in)famous instance is the 1938 War of the Worlds radio adaptation from H.G. Welles's science fiction story. The story was not announced as fiction when it aired and caused a mass panic.

viii The importance of Welles's voice is such that Garis finds it ties together all the roles he played in his entire career (2004: 56).

ix 'When we talk about race relations in America or racial progress, it's all nonsense. There are no race relations. White people were crazy. Now they're not as crazy. To say that black people have made progress would be to say they deserve what happened to them before.' (Aker, 2014: para. 4)

${ }^{x}$ Desdemona is always already lost, as indicated by her name, which derives from the Greek dusdaimon: the unfortunate.

${ }^{x i}$ When Desdemona rejects the idea that Othello could be jealous - 'Who, he? I think the sun where he was born / Drew all such humours from him' (3.4.29-30) - she responds to how trusting he has emphatically shown himself to her (and us) thus far. At the same time, this reply is clearly ironic to Shakespeare's contemporaries for a 'linkage between hot climates and hot passions [were] an Elizabethan cliché' (McLendon, 1997: 128), and scholars suggest that Othello's 'jealousy itself would have been decoded as a racial sign by an audience at the time of the initial performances' (Butler-Evans: 1997: 149).

${ }^{x i i}$ Ferber illuminates this paradoxical worldview with some historical detail; for instance, distinctively from British law, these children were defined in line with their mother's origin.

xiii Hunter underlines the 'daring theatrical novelty - a black hero' at a time which loved imitation and disregarded originality (1967: 139). 


\section{References}

Aker, Angie (2 December 2014), Chris Rock's Epic Truth Bomb About How It's White People That Have Progressed, Not Black People,

http://www.upworthy.com/chris-rocks-epic-truth-bomb-about-how-itswhite-people-that-have-progressed-not-black-people, accessed 27

February 2017

Baldwin, James (1984), On Being White, http://faculty.gordonstate.edu/ Isanders-senu/On\%20Being\%20White\%20and\%20Other\%20Lies.pdf, accessed 22 February 2017

Bartels, Emily C. (1990), 'Making More of the Moor: Aaron, Othello, and Renaissance Refashionings of Race', Shakespeare Quarterly, 41 (4), 436453

Barthelemy, Anthony (1994), 'Introduction', in Barthelemy, Anthony (ed.), Critical Essays on Shakespeare's Othello, New York: Hall, pp. 162-86

Bhabha, Homi K. (1994), The Location of Culture, London: Routledge Boose, Lynda (1994), 'Othello's Handkerchief: "The Recognizance and Pledge of Love"', in Barthelemy, Anthony (ed.), Critical Essays on Shakespeare's Othello, New York: Hall, pp. 55-67

Buchman, Lorne M. (1991), 'Naming Time: Orson Welles's Othello', in Buchman, Lorne M. (ed.), Still In Movement: Shakespeare on Screen, New York: Oxford University Press, pp. 126-145

Bulik, Mark (8 September 2015), '1854: No Irish Need Apply', https:// www.nytimes.com/2015/09/08/insider/1854-no-irish-need-apply. html? $r=0$, accessed 8 April 2017

Burton, Jonathan (1998), 'A most wily bird: Leo Africanus, Othello and the trafficking in difference', in Loomba, Ania and Orkin, Martin (ed.), PostColonial Shakespeares, New York: Routledge, pp. 43-63

Butler-Evans, Elliott (1997), "'Haply, for I Am Black": Othello and the Semiotics of Race and Otherness', in Mythili, Kaul (ed.), Othello: New Essays by Black Writers, Washington: Howard University Press, pp. 139-50 Citizen Kane (dir. by Orson Welles, 1941)

Coates, Ta-Nehisi (2015), Between the World and Me, New York: Spiegel \& Grau.

Damani, Seba (17 March 2014), The Black Irish: Historical Memory of an Afrikan Past?, http://www.sebadamani.com/blog/the-black-irishhistorical-memory-of-an-afrikan-past, accessed 22 February 2017 
Delgado, Richard and Stefancic, Jean (eds.) (1997), Critical White Studies: Looking Beyond the Mirror, Philadelphia: Temple University Press

Drum, Kevin (3 March 2016), A Very Brief History of Super-Predators' http://www.motherjones.com/kevin-drum/2016/03/very-brief-historysuper-predators, accessed 27 February 2017

Dyer, Richard (1997), White: Essays on Race and Culture, London: Routledge

Fanon, Frantz (1967), Black Skin/White mask, New York: Grove Press (originally published by Editions de Seuil as Peau Noire, Masques Blanc in 1952)

Ferber, Abby L. (1998), White Man Falling: Race, Gender, And White Supremacy, Oxford: Oxford University Press

Fineman, Joel (1994), 'The Sound of O in Othello: The Real of the Tragedy of Desire', in Barthelemy, Anthony (ed.), Critical Essays on Shakespeare's Othello, New York: Hall, pp. 104-64

Frye, Brian (February 2006: 38), The Hearts of Age, Senses of Cinema, http://sensesofcinema.com/2006/cteq/hearts of age/, accessed 22 February 2017

Garis, Robert (2004), The Films of Orson Welles, New York: Cambridge. Hadfield, Andrew (2002), "'The gross clasps of a lascivious Moor." The Domestic and Exotic Contexts of Othello', in Hadfield, Andrew (ed.), A Routledge Literary Sourcebook on William Shakespeare's Othello, London: Routledge, pp. 92-94

Hale, Grace E. (1998), Making Whiteness: The Culture of Segregation in the South, 1890-1940, New York: Pantheon

Higham, Charles (1970), The Films of Orson Welles, Berkeley: University of California Press

Hunter, G. K. (1967), 'Othello and Color Prejudice', Proceedings of the British Academy, 53, 139-63

Ignatiev, Noel (1005), How the Irish became White, New York: Routledge Jardine, Lisa (2002), "'Why should he call her whore?" Defamation and Desdemona's Case', Hadfield, Andrew (ed.) A Routledge Literary Sourcebook on William Shakespeare's Othello, London: Routledge, pp. 8491

Jorgens, Jack J. (1976), 'Welles' Othello: A Baroque Translation', in Gottesman, Ronald (ed.) Focus on Orson Welles, Englewood Cliffs:

Prentice-Hall, pp. 67-156 
Jorgens, Jack J. (1977), Shakespeare On Film, Bloomington: Indiana University Press

Loomba, Ania (1998), 'Issues of race, hybridity and location in post-colonial Shakespeares', in Loomba, Ania and Orkin, Martin (eds.), Post-Colonial Shakespeares, New York: Routledge, pp. 143-64

Loomba, Ania (1994), 'Sexuality and Racial Difference', in Barthelemy, Anthony (ed.), Critical Essays on Shakespeare's Othello, New York: Hall, pp. $162-86$

López, Ian F. H. (1996), White by Law: The Legal Construction of Race, New York und London: New York University Press

Lott, Eric (1993), Love and theft: Blackface minstrelsy and the American working class, New York: Oxford University Press

Lott, Eric (1997), 'The Whiteness of Film Noir' in Hill, Mike (ed.), Whiteness: A Critical Reader, New York und London: New York University Press, pp. 81- 101

McBride, Joseph (1976), 'Welles Before Kane', Gottesman, Ronald (ed.), Focus on Orson Welles, Englewood Cliffs: Prentice-Hall

McLendon, Jacquelyn Y. (1997), "'A Round Unvarnished Tale":

(Mis)Reading Othello or African American Strategies of Dissent', in Mythili, Kaul (ed.), Othello: New Essays by Black Writers, Washington: Howard University Press, pp. 121-37

McPherson, David (2002), 'Othello and the Myth of Venice', in Hadfield, Andrew (ed.) A Routledge Literary Sourcebook on William Shakespeare's Othello, London: Routledge, pp. 78-83

Metz, Walter (2004), Engaging Film Criticism: Film History and Contemporary American Cinema, New York: Peter Lang

Morrison, Toni (1990), Playing in the Dark: Whiteness and the Literary Imagination, New York: Vintage Books

Newman, Carol Thomas (1994), 'Femininity and the Monstrous in Othello', in Barthelemy, Anthony (ed.), Critical Essays on Shakespeare's Othello, New York: Hall, pp. 124-61

Neely, Carol Thomas (1994), 'Women and Men in Othello', in Barthelemy, Anthony (ed.), Critical Essays on Shakespeare's Othello, New York: Hall, pp. $68-90$

Neill, Michael, 'Unproper Beds: Race, Adultery, and the Hideous in Othello', in Barthelemy, Anthony (ed.), Critical Essays on Shakespeare's Othello, New York: Hall, pp. 187-215 
Ogude, S.E. (1997), 'Literature and Racism: The Example of Othello', in Mythili, Kaul (ed.), Othello: New Essays by Black Writers, Washington: Howard University Press, pp. 151-66

Othello (dir. by Orson Welles, 1951)

Posner, Bruce C. (ed.) (2001), Unseen Cinema: Early American Avant-garde Film 1893-1941, New York: Anthology Film Archives

Racism against Irish refugees - we should know our own history (14 September 2015), http://www.wsm.ie/c/racism-against-irish-refugeesfamine, accessed 22 February 2017

Rosenthal, Daniel (2000), Shakespeare on Screen, London and Glasgow: Hamlyn.

Rothwell, Kenneth S. (1999), A History of Shakespeare on Screen: A Century of Film and Television, Cambridge: Cambridge University Press

Schabert, Ina (1992), Shakespeare-Handbuch, Stuttgart: Kröner (3rd ed.)

Shakespeare, William (1965), 'Othello, The Moor of Venice', in Alexander, Peter (ed.), William Shakespeare: The Complete Works, London and Glasgow: Collins, pp. 1114-54

Sign of the times of racism in England that was all too familiar (22 October 2015), https://www.theguardian.com/world/2015/oct/22/sign-of-thetimes-of-racism-in-england-that-was-all-too-familiar, accessed 22 February 2017

Simon, William G. (1989), 'Orson Welles: an Introduction', in Simon, William G. (ed.) Persistence of Vision, no.7 pp. 5-11

Sjögren, Gunnar (2002), 'Was Othello Black?', Shakespeare and Scandinavia: A collection of Nordic studies, in Sorelius, Gunnar (ed.), Newark: University of Delaware Press, pp. 44-64

Stallybrass, Peter (1986), 'Patriarchal Territories: The Body Enclosed', in Ferguson, Margaret W., Quilligan, Maureen, and Vickers, Nancy (eds.), Rewriting the Renaissance', Chicago: Chicago University Press

Stam, Robert (1995), 'Orson Welles, Brazil, and the Power of Blacknes', in Beja, Morris (ed.), Perspectives on Orson Welles, New York: Hall, pp. 21944

The Hearts of Age (dir. by Orson Welles, 1934)

Touch of Evil (dir. by Orson Welles, 1958)

Welsh, James M., Vela, Richard and Tibbott, John C. (2002), Shakespeare into Film, New York: Checkmark Books 
White, R.S. (1986), Innocent Victims: Poetic Injustice in Shakespearean Tragedy, London: Athlone Press (2nd edn)

Williams, John A. (1997), 'Who Is Desdemona', in Mythili, Kaul (ed.), Othello: New Essays by Black Writers, Washington: Howard University Press, pp. 113-17

\section{To cite this article:}

Jung, N. (2017). 'For they need to believe themselves White: An intertextual analysis of Orson Welles's Othello'. Exchanges: The Warwick Research Journal, 4(2), 244-261. Retrieved from: 